\title{
Politeness Strategies in Thai Graduate Research Paper Discussions: Implications for Second/Foreign Language Academic Writing
}

\author{
Kunyarut Getkham ${ }^{1}$ \\ ${ }^{1}$ Graduate School of Language and Communication, National Institute of Development Administration (NIDA), \\ Bangkok, Thailand \\ Correspondence: Kunyarut Getkham, Graduate School of Language and Communication, National Institute of \\ Development Administration (NIDA), Bangkok, Thailand. E-mail: kanyaratg4@gmail.com
}

Received: March 4, 2014 Accepted: September 28, 2014 Online Published: October 23, 2014

doi:10.5539/elt.v7n11p159 URL: http://dx.doi.org/10.5539/elt.v7n11p159

\begin{abstract}
This paper investigates the use of politeness strategies in 32 discussion sections of research papers produced by Thai graduate students at Graduate School of Language and Communication, National Institute of Development Administration (NIDA), Bangkok, Thailand. The study reported in this paper adopts Brown and Levinson's $(1978,1987)$ and Myers' (1989) models of politeness strategies. The project as a whole aims to identify what politeness strategies are most commonly used in the whole corpus, whether differences exist in the use of these politeness strategies and how politeness strategies are employed. The analysis of the data reveals that these student researchers rarely employed politeness strategies in their discussions. However, they used more negative politeness strategies than the positive ones and the differences in the use of these two strategies were highly significant. This study provides some pedagogical implications for ESL/EFL academic writing and syllabus designing.
\end{abstract}

Keywords: academic writing, corpus-based study, EFL/ESL, politeness strategies, research paper, Thai students

\section{Introduction}

Criticizing or questioning empirical evidence or existing theories may be interpreted as impolite if not expressed in an acceptable manner. Such statements can intimidate face-images or can be seen as face-threatening acts (Brown \& Levinson, 1987). When making claims, criticizing, speculating or asserting empirical evidence, writers should use politeness strategies to show that they are aware of the different status and roles. Moreover, Hyland (1999) states that there is often more than one interpretation for a given piece of data. Therefore, research writers should employ politeness strategies when making their claims since any statement the writers claim to be true requires the ratification of the readers. In other words, to gain acceptance from the authority in their fields, writers should use several strategies aimed at persuading the authority of the truth of their claims.

Over recent decades, concern about the use of politeness strategies in scientific writing has increased. Several studies have been conducted to investigate politeness strategies used by research writers when presenting factual information along with writers' personal opinions and when interacting with readers (Getkham, 2011, 2012, 2013; Salom \& Monreal, 2009; Harwood, 2005; Hunston, 1994; Hyland, 2001; Myers, 1989, 1992; Skelton, 1997, Walko, 2007). However, to the best of my knowledge, research studies quantitatively investigating the use of politeness strategies in student research writing have been scarce. To this end, I attempt to quantitatively and qualitatively analyze a corpus of 32 student research papers in language and communication. The analysis will shed light how politeness strategies are used in these student papers. The findings will help instructors, especially research advisors, know which strategies were lacked and which need to be provided for their students in order to help them know how information should be politely presented, argued, and supported.

\section{Review of Related Literature}

Brown and Levinson $(1978,1987)$ adopted Grice's (1975) conversational maxims and established a model of politeness strategies involving the classification of 'face' which represents what people desire and what motivates them. Defined as "the public self-image that every member wants to claim for himself" (p. 61) face is categorized into positive face and negative face (Brown \& Levinson, 1978, 1987). As face can be damaged, retained or enhanced, one should be aware of any possible actions that can pose a threat to face. Such actions are 
referred to as "Face Threatening Acts" (FTAs). Brown and Levinson $(1978,1987)$ have proposed politeness strategies aimed at avoiding FTAs which include both positive politeness strategies, negative politeness strategies and 'off record' strategies.

There have been numerous studies investigating, analyzing or examining politeness strategies over recent decades (Getkham, 2011; Salom \& Monreal, 2009; Harwood, 2005, Hunston, 1994; Hyland, 1996, 2001, 2002, 2005, 2008; Myers, 1989, 1992; Skelton, 1997, Walko, 2007). Some of these studies have centered on the use of hedging as a politeness strategy to minimize claims (Hyland, 1999), as face-saving devices (Halliday, 1994), as a means of gaining ratification for claims from a powerful peer group (Hyland, 1996, p. 434) and as a way of showing politeness (Myers, 1989; Salvager-Meyer, 1994). One of the major arguments relating to the use of hedging as a politeness strategy is on how it is used in different contexts or sections of research articles. Some researchers contend that hedges are most frequently utilized in the discussion section of articles (Burrough-Boenisch, 2005; Lau, 1999; Salager-Meyer, 1994) while others (e.g. Varttala, 1999) argue that they are found both in Discussion and results sections of articles.

Additionally, some studies have examined the functions and types of hedges in different sections of research articles, in various languages and disciplines and in both soft and hard sciences (Crompton, 1997; Falahati, 2009; Getkham, 2010; Lin \& Liou, 2006; Vassileva, 2001). Falahati (2009) examined a corpus of 25,983 words from articles in medicine, chemistry and psychology and found several cross-disciplinary variations in terms of statistical frequency and types of hedges. This study also supports previous research (e.g. Burrough-Boenisch, 2005) which contends that hedges mostly occur in the discussion section. In 2001, Vassileva found that there are cross-linguistic differences in terms of the type of hedges used within Bulgarian and English articles. Similarly to Vassileva (2001) and Nivales (2011) investigated variations in terms of the degree of involvement of Filipino writers across different disciplines and found significant interdisciplinary differences in the use of hedges. In addition to cross-linguistic and interdisciplinary differences in using hedges, Getkham (2011) revealed inter-corpus variations of hedging devices in different journals in the field of applied linguistics. However, in her study the highest incidence of hedging devices was in the introduction section of research articles. These studies mentioned above show several disparities in their findings.

Another interesting area in this field of study is the use of first person pronouns by writers in positioning themselves within their claims. For instance, in 2001, Hyland studied the use of first person pronouns in 240 research articles from different disciplines in both soft and hard sciences. He concluded that there are significant interdisciplinary differences among research articles. Additionally, in 2002, by cross-comparing the functions of $I$, we, and their related cases within a collection of 64 project reports of students from different disciplines and a corpus of 240 research articles from professional journals, Hyland supported his previously claimed inter-disciplinary differences in terms of use of first person pronouns and added that professional writers tend to use more first person pronouns than their students and that this is more evident in disciplines belonging to soft sciences than in hard sciences. Other research studies found inter-corpus variations in the use of first person pronouns and reported the discussion section as possessing the highest occurrences of such discourse strategy (Li $\& \mathrm{Gi}, 2009$ ). Another interesting result is the co-occurring patterns of linguistic features and multi-dimensional variations in different research sections (Getkham, 2010) and the role of first person pronouns as a writers' strategy to increase reader involvement with their text through the use of first person we (Harwood, 2005).

With reference to positive and negative politeness strategies, some investigations have come up with some very interesting results (e.g. Myers, 1989; Skelton, 1997; Walko, 2007; Salom \& Monreal, 2009; Getkham, 2013). The findings of Myers (1989) in a research grounded in a corpus in the field of molecular genetics, indicated that FTAs, specifically claims and denial of claims in studies, naturally yields acts of imposition. Since authorial imposition is inherent to FTAs, writers remedy this with either positive or negative politeness strategies (Myers, 1989). He added that positive politeness strategies include the utilization of pronouns and certainty modifiers while negative politeness strategies involve different discourse devices such as constructing impersonality and hedging.

Other interesting findings are the strategic use of positive politeness devices in writers efforts to display solidarity and involvement with their readers, specifically utilizing certainty adjectives when presenting knowledge claimed in common (Salom \& Monreal, 2009), and the deliberate use of positive politeness in writers' expressions of sympathy and appreciation (Walko, 2007). Moreover, Martinez (2001) as part of a study into negative politeness strategies, investigated the frequency of impersonal constructions by examining a corpus collected from both hard and soft sciences. He reported that impersonal constructions are most frequently utilized in the results and discussion sections. In 2013, however, Getkham found interdisciplinary differences in the utilization of only positive politeness strategies although negative politeness strategies, especially 
impersonality constructions, are found to be most commonly used among research articles in three disciplines.

Although the studies described above report interesting and significant results, they show some disparities. This indicates that more research in this field of study is necessary in order to contribute to the existing knowledge base to enable us to understand the different functions and uses of politeness strategies in different contexts. Moreover, to the best of my knowledge, research studies quantitatively investigating the use of politeness strategies in ESL or EFL student research papers are scarce. Therefore, I have attempted to elucidate the politeness strategies most commonly used and how these strategies are employed in the discussion parts of Thai student research papers. This can provide insightful information for teaching EFL/ESL academic writing.

\section{Corpus and Method}

The corpus comprises 32 discussion sections of Thai student research papers in the Graduate School of Language and Communication, National Institute of Development Administration, Bangkok, Thailand during the period of 2010-2012. These papers were randomly selected from a pool of 100 papers to ensure an unbiased representative sample. The corpus consists of 47,694 words. I selected to study this section since I assume that this section is where research writers make the highest level of claims in line with the presentations of their findings. I adopted Brown and Levinson's $(1978,1987)$ and Myers' (1989) models of politeness strategies to investigate the presence of face-redressive politeness strategies in the corpus. I focused on positive politeness strategies used to gain approval from the community and negative politeness strategies used to mitigate imposition. Following are the data analysis and the results of the study.

\subsection{A Model for Analysis}

In this model, some positive politeness and negative politeness strategies adopted include a number of subcategories as explained below.

3.1.1 Positive Politeness Strategies (PPS) Refer to the Strategies Emphasizing Solidarity, Common Ground or Agreement

In this study, some strategies such as claiming common ground and showing that writer and reader are cooperators were analyzed. Followings are explanations of the strategies.

The first strategy (PPS1) "claiming common ground" includes two sub-strategies:

ppss1.1 "Claiming common views, attitudes and opinions" by the use of:

a) Modifiers assuming common ground: an amazing sequence, an unexpected issue, etc.

b) Certainty adjectives: clear, obvious, certain, sure, undoubted, definite etc.

c) Alternative or speculative expressions: assumption, assume, assuming, speculate, speculation, speculating, etc.

ppss 1.2 "Creating rapport" by the use of:

a) Rhetorical questions: how does, why does, when does, what does, where does, how is, why is, when is, where is, what is, where is, etc.

b) Imperatives...note that, recall that, observe, see table, see figure, please refer to, as shown in, etc

c) Emotional responses to express personal attitude: fortunately, unfortunately, interestingly, surprising, etc.

The second strategy (PPS2) "showing that writer and reader are cooperators" include the inclusive "we" and its related cases.

3.1.2 Negative Politeness Strategies (NPS) Refer to the Strategies Attempting to Distance or Minimize the Imposition

In this study, some strategies such as being tentative by hedging, showing you do not want to impose or dissociating yourself from the statement, and attributing all responsibility were analyzed.

The first strategy (NPS1) "being tentative by hedging" includes:

a) The modal verbs: may, might, would, could;

b) The modifiers: probably, possibly, probable, possible, likely etc.;

c) The tentative verbs: suggest, indicate, seem, appear, tend, etc.

The second strategy (NPS2) "showing you do not want to impose: includes:

a) The phrases such as these observations suggest, these results imply, this leads to the proposal, etc.; 
b) The passive voice without an agent

c) Introductory phrase... it seems, it is interesting to, etc.

The third strategy (NPS3) "attributing all responsibility" includes first personal pronouns followed by performative verbs: we reported, we concentrated, I reported, I concentrated, etc.

\subsubsection{Frequency Counts}

The Mono Conc. Pro 2.2 (Barlow, 2004), a concordancing program recommended by experts such as Reppen (2001), was used to find the frequency of each politeness strategy. Then these frequencies were recorded in a spreadsheet. In addition to the automated counting, when the frequency counts involved the pronoun "we" and its related cases, all cases were investigated in context to ensure that they were inclusive first person pronoun uses and to determine their pragmatic function. In other words, all forms of we, us, and our referring to reader and writer were counted as an inclusive pronoun since there is a possibility that the use of "we" and its related cases may be used as exclusive first person pronoun to claim authority and exhibit some form of ownership of the content (Hyland, 2001, 2002) rather than creating rapport.

\subsubsection{Data Analysis}

Research Question 1 What politeness strategies are most commonly used in the papers? The descriptive statistics was used to find the averages of the total positive and total negative strategies in the whole corpus. In addition, these statistics were used to find the average of the occurrence of politeness at macro and micro levels. Also, several devices used to realize those strategies, i.e. sub-strategies, were elucidated.

Research Question 2 Do differences exist in the use of positive and negative politeness strategies in the whole corpus? The paired sample t-test was used to determine the differences in the use of positive and negative politeness strategies in the whole corpus. The confidential level was set at .05 .

\section{Findings}

\subsection{The Use of Politeness Strategies}

The first research question investigates the most commonly used politeness strategies. The raw frequency of each device was normalized following Biber's (1995) method by having the raw frequency count divided by the number of words in the text and multiplied by 1000 . After that the normalized frequency of each device was recorded. Then the normalized frequencies of devices in positive strategies and those in negative strategies were added to produce the total positive strategies and the total negative strategies respectively. The frequencies of all devices in each sub-strategy were also added to produce frequencies of sub-strategies. After that descriptive statistics were calculated to find the averages of positive and negative politeness strategies and sub-strategies. The means and standard deviations for the two politeness strategies are presented in Tables 1-2.

Table 1. Averages of positive politeness strategies

\begin{tabular}{lll}
\hline Strategies/sub-strategies & Mean & SD \\
\hline Alternative & .06 & .20 \\
Certainty adjectives & .19 & .42 \\
Modifiers & .00 & .00 \\
ppss1.1 & .25 & .44 \\
Rhetorical questions & .00 & .00 \\
Emotional responses & .02 & .12 \\
Imperatives & .07 & .38 \\
ppss1.2 & .13 & .55 \\
PPS1 & .37 & .85 \\
PPS2(inclusive “we”) & .19 & .50 \\
All PPS & .52 & .84 \\
\hline
\end{tabular}


Table 1 shows that in the whole corpus the most commonly used positive politeness strategy is the first strategy "claiming common ground" (with an average of .37) and in this strategy, the first sub-strategy "claiming common views, attitudes, or opinions" is more commonly used than the second sub-strategy "creating rapport" (with an average of .25 and .13 respectively). The uses of modifiers and rhetorical questions were not found. The average of all positive politeness strategies is .52 .

Table 2. Averages of negative politeness strategies

\begin{tabular}{lll}
\hline Strategies/sub-strategies & Mean & SD \\
\hline Modals & 11.22 & 5.76 \\
Modifiers & .37 & .84 \\
Tentative verbs & 1.08 & 1.06 \\
NPS1 & 12.67 & 5.81 \\
Impersonal construction1 & .17 & .44 \\
Impersonal construction2 & 9.42 & 4.86 \\
Introductory phrase & .03 & .12 \\
NPS2 & 12.91 & 8.32 \\
NPS3 & .00 & .00 \\
All NPS & 22.28 & 9.14 \\
\hline
\end{tabular}

Table 2 shows that the second strategy "showing that you don't want to impose" and the first strategy "being tentative by hedging" are almost equally used in the whole corpus (with an average of 12.91 and 12.67 respectively). The average of all negative strategies is 22.28 .

\subsection{Differences in the Use of Positive and Negative Strategies}

The second research question investigates the differences in the use of positive and negative politeness strategies in the whole corpus. The paired sample t-test was used to determine the differences. The next table presents the results of the analysis.

Table 3. Differences in the use of positive and negative politeness strategies in the whole corpus

\begin{tabular}{|c|c|c|c|c|c|c|c|c|}
\hline & \multicolumn{5}{|c|}{ Paired Differences } & \multirow{3}{*}{$\mathrm{t}$} & & \\
\hline & \multirow{2}{*}{ Mean } & \multirow{2}{*}{ SD } & \multirow{2}{*}{ SD. Mean } & \multicolumn{2}{|c|}{$95 \%$ Confidence Interval of the Difference } & & & $\mathrm{P}$ \\
\hline & & & & Lower & Upper & & & \\
\hline Pair 1 PPS-NPS & -21.76 & 9.31 & 1.65 & -25.11 & -18.40 & -13.218 & 31 & .000 \\
\hline
\end{tabular}

Table 3 reveals that the writers in this corpus more frequently used negative politeness strategies than positive politeness strategies. This difference in the use of strategies was highly significant $(\mathrm{P}<.001)$.

\section{Discussion}

In general, it was found that that though these student researchers rarely employed politeness strategies in their discussions, they used more negative politeness strategies than the positive ones and the difference in the use of these two strategies is statistically significant at $\mathrm{P}<.001$. This finding is consistent with previous studies (Getkham, 2013; Salom \& Monreal, 2009; Myers, 1989, 1992). The results also confirm Myers hypothesis that although a wide range of positive politeness strategies are available for research writers; references to the reader's positive face needs are very restricted. Generally, a greater use of negative politeness strategies should be expected. In the corpus, two negative politeness strategies ("being tentative by hedging" and "showing that you don't want to impose") were employed. Moreover, the most frequently used negative politeness strategy was "showing you don't want to impose". In the following section, the use of strategies is discussed in two parts: positive politeness and negative politeness strategies. 


\subsection{Positive Politeness Strategies}

Although the averages of the positive politeness strategies used are very low, these student writers employed them strategically (average of .52) to gain approval of the readers and to minimize the distance between writer and reader. As indicated by Myers (1989) research writers use several strategies to show positive politeness such as strategic use of modifiers assuming common ground. The most commonly used positive politeness strategy was the first strategy "claiming common ground" (with an average of .37) and in this strategy, the first sub-strategy "claiming common views, attitudes, or opinions" was more commonly used than the second sub-strategy "creating rapport" (with an average of .25 and .13 respectively). This finding is consistent with those of Salom and Monreal (2009), Myers (1989), and Getkham's (2013). To claim common ground, they mostly used certainty adjectives, followed by speculative expressions but they did not use modifiers. The writers in this corpus rarely created rapport by using imperatives (with an average of .07), followed by the use of emotional responses; however, they did not employ rhetorical questions.

The following sentences show how positive politeness strategies were used. For example, these student writers used certainty adjectives to persuade readers to join the argument by presenting certain views (see samples 1 to $3)$.

(1) It is clear that these twenty-three techniques can make the receptor language flow naturally, especially by using these three outstanding techniques: Negated antonyms, Doublets, and Skewing. (RA 9)

(2) It is certain that the advertisements switch from Thai to English more than from English to Thai. (SA 6)

(3) It is obvious that the translators took the criteria of social status, gender, number, and politeness into consideration when translating. (SA-6)

In addition, alternative or speculative expressions were used to show solidarity and involvement with readers. Writers assumed that readers shared the idea behind what they were claiming or the information that the writers might be criticizing. (See sample 4)

(4) It is reasonable to assume that the three prominent data categories characterized were used to encourage interest and enjoyment in the fictional narrative since they were employed in the translation to enhance the natural sense and style of the Thai language. (SA-2)

In addition to "creating common views", "creating rapport" was employed including imperatives and emotional responses. Writers used imperatives to make readers feel closer to the research by asking them to do something (see sample 5).

(5) For example, in this study, the word "hurt" is translated as "pain and ache," and the word "wonderful" is translated as "miracle and strange." see Table 3, (RA 9)

To show solidarity writers express emotion toward their research results (see sample 6)

(6) Not surprisingly, the overall anxiety level of American respondents is on the low level. (RA-2)

With reference to the second strategy "showing that writer and reader are cooperators", the inclusive pronoun "we" and its related case are not favored by these writers (average $=.19$ ). The use of first person plural pronouns conveys the idea that readers are perceived as colleagues or as fellow researchers and that the writers want to reduce the gap between writer and reader (Harwood, 2005; Li \& Gi 2009) and bring readers into the text (Hyland, 2002, 2005, 2008). However, the writers in this study, who were student researchers, were less likely to use this device. This suggests that positive politeness strategies aimed at decreasing distance between writer and reader may not have been favored. See the following samples.

(7) As we can see from previous chapters, the speakers who are the main characters from the movie Romeo and Juliet use many different personal pronouns in many different situations. (RA 8)

(8) Based on these interviews, we can conclude that the major factors were language, cultural background knowledge, historical background, differing communication styles, ways of thinking and values. (SA 3)

\subsection{Negative Politeness Strategies}

The fact that negative politeness strategies are the most common type of politeness used by these student writers agrees with the findings of previous studies (i.e. Getkham, 2013; Salom \& Monreal, 2009; Myers, 1989). This study found that these student researchers seem to use the two strategies: "being tentative by hedging" and "showing you don't want to impose" in equal proportion (with an average of 12.91 and 12.67 respectively) but none used the third strategy "attributing all responsibility". This finding is consistent with Hyland (2001) in that student writers tend to use less first person pronouns than professional writers. He also mentioned that this is 
more evident in disciplines belonging to soft sciences than hard sciences.

With regard to the first strategy "being tentative by hedging", modals, tentative verbs, and modifiers, as might be expected, are most commonly used in the discussion section. This finding is consistent with previous works (Burrough-Boenisch, 2005; Falahati 2009; Lau, 1999; Myer, 1989; Salager-Meyer, 1994; Varttala, 1999). According to Hyland (1999), the discussion section contains mainly interpretations or tentative propositions for the research results. Research writers need to gain acceptance for their claims from established authorities in their relevant fields and use several strategies aimed at persuading such authorities of the truth of their claims. In so doing, politeness strategies are mostly used to mitigate claims or denials of claims (Hyland, 1996). The hedges can help writers to present unproven claims with prudence and mitigate assertions. Hedges can also offer discursive room in which readers are able to contend the writer's arguments and interpretations, thereby enabling writers to take a position with respect to an audience as well as to facts. It is obvious that student writers in this study used hedging devices mostly as a means of showing politeness (Myers, 1989; Salager-Meyer, 1994).

The use of hedging devices as a means to express politeness suggests that research writing is very conventional (see samples 1 and 2). In the first example, the writer used a modal "may" and in the second example, the writer used a modifier "likely".

(1) To sum up, the differences between large and small size advertising types may occur because of the amount of advertising space. (RA 4)

(2) For some pupils, identifying the main idea of the passage was likely to prove difficult for them, particularly in the case of those taught by using English. (Special A 4)

The use of tentative verbs can also be seen in the following example.

(3) The result shows that the comic resonance seems to simulate friendlier and trendier interaction in the cyber speech. (RA 3)

With regard to the second strategy "showing that you don't want to impose", as might be expected, in this strategy, the passive voice without an agent is most commonly used. This suggests that research writing is very impersonal (see samples 4 to7).

(4) Borrowed words are used in the translated text because the meaning of the word in SL is known to the most RL readers, for example; yoga, shampoo, and website are already known by most Thai readers. (RA 2)

(5) Moreover, all the slogans seem to be used for persuading, assuring, and impressing their customers. (RA-5)

(6) In sum, many signs were found in the television commercials of EGAT and MEA, with one thing in common: electrical services for Thai people. (SA 1)

(7) Secondary Sense, Implicit Meaning and Skewing are discussed as follows. (SA-2)

In conclusion, it should be noted that on the average, negative politeness strategies, especially impersonality devices and hedges, are the most common strategies used by these student researchers. This suggests that research writing is very impersonal and limited by convention. The use of politeness strategies suggests that writing and reading are interactive and politeness strategies play a vital role.

\section{Conclusions}

Several conclusions can be drawn from the findings of this study. First, the infrequent use of politeness strategies by the student writers in this study indicate an urgent need for instruction in certain rhetorical structures since academic/research writing is more than presenting a collection of facts. It also presents writers' views and demonstrates their manners (Hyland, 2005). It should be noted that Grice's (1975) Cooperative Principle, especially his maxim of manner, as well as the FTA model (Brown \& Levinson, 1987), play a crucial role in the research genre. Second, the fact that negative politeness strategies and especially impersonality devices and hedges are common strategies used by these student writers indicates a preference to mitigate their commitment to propositions. Findings revealed that impersonal constructions were mostly used. It should be noted that the use of impersonality plays a vital role in downplaying the importance of human intervention. This suggests that research writing is very impersonal and limited by convention (Hyland, 1999). The use of hedging devices also plays an important part in the discussion section where writers mitigate the imposition on readers and reduce writers' commitment to the truth of their claims. Finally, student researchers may not be aware of available devices, especially positive strategies, to politely present their views in discussion sections. This may reflect the more conventional style of academic training in the Thai context. It seems reasonable to suggest that positive politeness strategies might be valued in academic writing. 


\section{Implications}

Findings that student writers in this study rarely used available devices to politely present their views and make claims in the discussion sections of their research papers may inform course designers of genre structures relevant to research or academic writing curriculums. For example, when developing teaching materials, ESL/EFL academic writing instructors should include several devices; each identified for particular functions, such as the positive politeness strategies: imperatives, rhetorical questions, emotional responses; and the negative politeness strategies: first person pronoun followed by performative verbs. In addition, for non-native English speaking students, training in awareness of different kinds of politeness strategies as well as the relationships among functions and language would enhance their ability to acquire skills in academic writing.

Teachers of ESL/EFL academic writing should guide students to use available rhetorical options for interactional purposes. It is possible to provide a template for structuring academic writing. This template may be built up from exemplary quotations in the text, to provide assistance to student writers. Moreover, the corpus can be used as an authentic example of research papers. Teachers can make suggestions to students as they research the language using a data-driven, inductive approach (Beatty, 2003). With teacher encouragement, this process can both stimulate students' curiosity and encourage them to actively and independently engage with the language. Incorporating this actual strategy into the curriculum may help students efficiently read and to eventually write this style of discourse in order to increase the chance of having their papers accepted for publication.

\section{References}

Barlow, M. (2004). MonoConc Pro 2.2. Texas: Athelstan.

Biber, D. (1995). Variation across speech and writing. Cambridge: Cambridge University Press.

Brown, P., \& Levinson, B. (1978). Universals of Language: Politeness Phenomena, in E. Goody (Ed.), Questions and Politeness. Cambridge: Cambridge University Press.

Brown, P., \& Levinson, S. (1987). Politeness: Some universals in language usage. Cambridge: Cambridge University Press.

Burrough-Boenisch, J. (2005). NS and NNS scientists' amendments of Dutch scientific English and their impact on hedging. English for Specific Purposes, 24(1), 25-39. http://dx.doi.org/10.1016/j.esp.2003.09.004

Crompton, P. (1997). Hedging in academic writing: Some theoretical problems. English for Specific Purposes, 16(4), 271-287. http://dx.doi.org/10.1016/S0889

Falahati, R. (2007). The use of hedging across different disciplines and rhetorical sections of research articles. In N. Carter, L. H. Zabala, A. Rimrott, \& D. Storoshenko (Eds.), Proceedings of the 22nd Northwest Linguistics Conference (NWLC) at Simon Fraser University (pp. 99-112). Burnaby, Canada: Linguistics Graduate Student Association.

Fraser, B. (1990). Perspectives on politeness. Journal of Pragmatics, 14(2), 219-236.

Getkham, K. (2010). A corpus-based study of Applied Linguistics research articles: A multidimensional analysis. In I. Moskowich-Spiegel Fandino, B. Garcia, J. Martin, \& P. Sandino, (Eds.), Proceedings from Language windowing through corpora: Visualizacion del lenguaje a traves de corpus. Part I. CILC $2^{\text {nd }}$ International conference on corpus linguistics. University of A Coruna, Spain.

Getkham, K. (2011). Hedging Devices in Applied Linguistics Research Articles. In A. J. West, K. Getkham, \& J. Singhakowinta (Eds.), Proceedings of the $3^{\text {rd }}$ International Conference on Language and Communication (ICLC) at National Institute of Development Administration, Bangkok, Thailand.

Getkham, K. (2013). Politeness strategies in research Articles: A cross-disciplinary study. Paper presented at AACL International Conference, San Diego State University, California, USA.

Salom, L. G., \& Monreal, C. S. (2009). Interacting with the reader: Politeness strategies in engineering research article discussions. Journal of English Studies, 9(S1), 175-189. http://dx.doi.org/10.6018/ijes.1.1.99581

Grice, H. P. (1975). Logic and conversation. In P. Cole, \& J. Morgan (Eds.), Syntax and semantics: Speech acts, 3, 41-58. New York: Academic.

Halliday, M. (1994). Introduction to functional grammar (2nd ed.). London: Arnold.

Harwood, N. (2005). We do not seem to have a theory ... The theory I present here attempts to fill this gap': Inclusive and exclusive pronouns in academic writing. Applied Linguistics, 26(3), 343-375. http://dx.doi.org/10.1093/applin/ami012 
Hunston, S. (1994). Evaluation and organization in a sample of written academic discourse. In M. Coulthard (Ed.), Advance in written text analysis (pp. 121-161). London: Routledge.

Hyland, K. (1996). Writing without conviction: Hedging in science research articles. Applied Linguistics, 17(4), 433-454. http://dx.doi.org/10.1093/applin/17.4.433

Hyland, K. (1999). Disciplinary discourse: Writer stance in research articles. In C. Candlin, \& K. Hyland (Eds.), Writing: Texts, processes and practices (pp. 99-121). Harlow: Addison-Wesley Longman.

Hyland, K. (2001). Humble servants of the discipline: Self-mention in research articles. English for Specific Purposes, 20(3), 207-226. http://dx.doi.org/10.1016S0-00012(00)4906-0889

Hyland, K. (2002). Authority and invisibility: Authorial identity in academic writing. Journal of Pragmatics, 34(8), 1091-1112. http://dx.doi.org/10.1016/S0378-2166(02)00035-8

Hyland, K. (2005). Stance and engagement: a model of interaction in academic discourse. Discourse Studies, 7(2), 173-191. http://dx.doi.org/10.1177/1461445605050365

Hyland, K. (2008). Small bits of textual material: A discourse analysis of Swales'writing. English for Specific Purposes, 27(2), 143-160. http://dx.doi.org/10.1016/j.esp.2006.10.005

Lau, H. H. (1999). Hedging expressions as signals of evidence in academic journal discourse. The Proceedings of the Eighth International Symposium on English Teaching (pp. 431-440). Taipei: The Crane Publishing Company. (NSC-88-2411-H-007-018).

Li, L. J., \& Ge, G. C. (2009). Genre analysis: Structural and linguistic evolution of the English-medium medical research articles (1995-2004). English for Specific Purposes, 28(2), 93-104. http://dx.doi.org/10.1016/j.esp.2008.12.004

Lin, M. C., \& Liou, H. C. (2006). Development of online materials for academic English writing: Contribution of text analysis on the discussion section of research articles. Proceedings of the 23rd International Conference on English Teaching and Learning in the ROC V. 2 (pp. 862-875).

Martinez, I. (2001). Impersonality in the research article as revealed by analysis of the transitivity structure. English for Specific Purposes, 20(3), 227-247. http://dx.doi.org: 10.1016/S0889-4906(00)00013-2

Myers, G. (1989). The pragmatics of politeness in scientific articles. Applied Linguistics, 10(1), 1-35. http://dx.doi.org/10.1093/applin/10.1.1

Myers, G. (1992). "In this paper we report..." Speech acts and scientific facts. Journal of Pragmatics, 17(4), 295-313. http://dx.doi.org/10.1016/0378-2166(92)90013-2

Nivales, M. L. (2011). Hedging in college research papers: Implication for language instruction. The Asian-EFL Journal, 13(4), 35-45. http://dx.doi.org/10.1016/j.sbspro.2014.03.611

Salager-Meyer, F. (1994). Hedges and textual communicative function in medical English written discourse. English for Specific Purposes, 13(2), 149-170. http://dx.doi.org/10.1016/0889-4906(94)90013-2

Skelton, J. (1997). The representation of truth in academic medical writing. Applied Linguistics, 18(2), 121-140. http://dx.doi.org/10.1093/applin/18.2.121

Thomas, J. (1995). Meaning in interaction: An introduction to Pragmatics. London and New York: Longman.

Varttala, T. (1999). Remarks on the communicative functions of hedging in popular scientific and specialist research articles on medicine. English for Specific Purposes, 18(2), 177-200. http://dx.doi.org/10.1016/S0889-4906(98)00007-6

Vassileva, I. (2001). Commitment and detachment in English and Bulgarian academic writing. English for Specific Purposes, 20(1), 83-102. http://dx.doi.org/10.1016/S0889-4906(99)00029-0

Walko, Z. (2007). EFL research articles through the lens of pragmatic politeness. WoPalP, 1, 1-16.

\section{Copyrights}

Copyright for this article is retained by the author(s), with first publication rights granted to the journal.

This is an open-access article distributed under the terms and conditions of the Creative Commons Attribution license (http://creativecommons.org/licenses/by/3.0/). 